\title{
Synthesis of New Curcumin Analogues from Kulit Lawang Oils Using the Conventional Method and Microwave
}

\author{
Imanuel Berly Delvis Kapelle ${ }^{1,2}$, Tun Tedja Irawadi ${ }^{3}$, Meika Syahbana Rusli ${ }^{2}$, \\ Djumali Mangunwidjaja ${ }^{2}$, Zainal Alim Mas'ud ${ }^{3}$ \\ ${ }^{1}$ Chemistry Department, Mathematic and Natural Science Faculty, Pattimura University, Maluku, Indonesia \\ ${ }^{2}$ Agricultural Industry Technology Department, Agriculture Technology Faculty, Bogor Agricultural Institute, Bogor, Indonesia \\ ${ }^{3}$ Chemistry Department, Mathematic and Natural Science Faculty, Bogor Agricultural Institute, Bogor, Indonesia
}

\section{Email address:}

berly_mollucas@yahoo.com (I. B. D. Kapelle)

\section{To cite this article:}

Imanuel Berly Delvis Kapelle, Tun Tedja Irawadi, Meika Syahbana Rusli, Djumali Mangunwidjaja, Zainal Alim Mas'ud. Synthesis of New Curcumin Analogues from Kulit Lawang Oils Using the Conventional Method and Microwave. Science Journal of Chemistry.

Vol. 3, No. 3, 2015, pp. 50-56. doi: 10.11648/j.sjc.20150303.13

\begin{abstract}
Kulit lawang oils are essential oils that are widely available in the Moluccas and oil major component contain eugenol and safrole. Safrole can be converted into value-added products that curcumin analogues. The purpose of this research is to synthesize new compounds curcumin analogues from kulit lawang oils. The steps being taken is isolation safrole, safrole isomerization and oxidation isosafrole produce piperonal. The method synthesis curcumin analogues with piperonal precursor with two methods: conventional and microwave. Results safrole isolation from skin oils mace using alkaline extraction method for 5 hours yield $19.30 \%$ were is characterized by GCMS, FTIR and ${ }^{1} \mathrm{H}-\mathrm{NMR}$. Isosafrole proceeds reaction isomerization safrole without the use of solvents for 6 hours at a temperature of $120^{\circ} \mathrm{C}$ obtained yield $77.56 \%$ with two products cisisosafrole (15.4\%) and trans-isosafrole (69.34\%) were characterized by GC, FTIR and ${ }^{1} \mathrm{H}$-NMR. Precursors piperonal which was resulting obtained from the oxidation reaction isosafrol using $\mathrm{KMnO}_{4}$ at temperature $<30{ }^{\circ} \mathrm{C}$ obtained yield $65.63 \%$ were characterized by GCMS, FTIR and ${ }^{1} \mathrm{H}$-NMR. Results synthesis curcumin analogues (1,5-Bis-benzo [1,3] dioxol-5-yl-penta1,4-dien-3-one) in the conventional method using $10 \% \mathrm{NaOH}$ catalyst for 3 hours at a temperature of $25^{\circ} \mathrm{C}$ be obtained yield $78.43 \%$ and synthesized using microwave at 140 watts for 2 minutes obtained yield $53.3 \%$.
\end{abstract}

Keywords: Kulit Lawang Oils, Safrole, Curcumin Analogues

\section{Introduction}

Kulit lawang oils are one of the potential essential oils and produced in eastern Indonesia especially Maluku and Papua. Plant kulit lawang included in family lauraceae and cinnamon group with characteristics slimy leaves, white wood, brittle and grow wild in the forest. Mace skin oils obtained from the distillation of the bark of lawang (Cinnamomum cullilawan, Blume) with yield 1.49 to $3.80 \%$ [14].

In the process of separation kulit lawang oils produces two products: eugenol (69.0\%) and safrole (21.0\%) [20]. Eugenol and safrole has a different structure, in which the epoxide ring safrole has a very active so it can be used as precursors of synthetic drugs. Safrole at room temperature is a colorless oil, but may turn yellow when exposed to sunlight, but at lower temperatures safrole is white crystal, has an odor sasafras and taste spicy $[10,28]$. Natural ingredients that have the same epoxide groups with safrole and has anti-cancer activity is piperine [25]. Piperine is an alkaloid compound that has been tested as an anti-tumor activity in vivo method can inhibit 56.8\% [6], antioxidant and hepatoprotective effects [18] and can increase the bioavailability [12]. Reactivity of the epoxide group owned by safrole can be used in a way converted into an anti-cancer drug products are derivatives of curcumin analogues.

Analog compounds (homologous) Curcumin is a compound that has the possibility of pharmacological properties similar or even better when compared to the parent compound. Curcumin is a cancer drug from natural ingredients that have been reported to have anti-cancer activity from ginger [19, 31]. Curcumin and curcumin analogues have biological activity as an anti-inflammatory, antioxidant, antitumor, and anti-cancer (gastrointestinal, 
breast, ovarian, lung, nerve) $[1,3,11,16,22]$. Effectiveness of each compound is influenced by differences in functional groups and structures that affect the physical-chemical properties and pleiotropic effects [2]. Some curcumin analogues with different functional groups in the test activity in vitro and in vivo pharmacokinetics showed that stability the mono-carbonyl analogues and pharmacokinetic profile increased significantly [17]. Based on data screening, quantitative relationship structure reactivity, indicates that substituents which have electron-withdrawing properties in the benzene ring greatly affect the anti-inflammatory properties [33]. Substituents on the carbon atom number-4 on phenol group is the active compound curcumin analogues [32], in the same group also synthesized with different substituents and tested in vitro activity against tumor cells [32], active side of curcumin analogues that provide these results is phenolic and conjugated double bonds [8].

One way to increase the added value of kulit lawang oils is synthesize compounds curcumin analogues as anticancer drugs. Process technology anticancer drugs (curcumin analogues) through several stages of include safrole isolation from kulit lawang oils, safrole isomerization, oxidation and condensation. Safrole can be isolated from kulit lawang oils by using chemical and physical methods. Chemical method using $\mathrm{NaOH}[13,20]$ while the physical method based on the difference in boiling point components. The principle of making isosafrole is isomerization; in which safrole will undergo structural changes due to the influence of the bases so it will happen shift double bond from straight chain approach towards benzene ring in conjugated position. Isomerization reaction mechanism via an intermediate (intermediate) is the formation of a carbocation which is the determinant of the rate of reaction, isomerization results are isosafrole with cis and trans isomers [13]. Safrole isomerization reactions generally use excess alkaline catalyst with process temperatures of $120 \mathrm{oC}$ for 6 hours [13] with a reaction without solvent. The oxidation process Isosafrole produces piperonal constitute alkene oxidation reaction, where the products are produced depending on the reaction conditions and the structure of the alkene used. Oxidation reactions performed using $\mathrm{KMnO} 4$ as an oxidizing agent in a two-phase system, that is water and the organic phase, then to increase reaction phase transfer catalyst added [20]. Phase transfer catalyst reaction takes place in two stages, the first stage of the transfer of the reactants from the normal phase to the second phase. The second step is the reactions between reactants are transferred to the second phase reactants and the reaction will run continuously until no more reactants to be transferred [21]. Oxidation of the double bond in alkenes dilute $\mathrm{KMnO} 4$ will produce diol and two $\mathrm{OH}$ groups on the diol compound is located on the same side. Diol formed is further oxidized to ketones, aldehydes or carboxylic acid [4]. In a very strong reaction conditions $(75 \circ \mathrm{C}, 0.2 \mathrm{M} \mathrm{KOH})$ $\mathrm{KMnO} 4$ can decide carbon-carbon double bond in alkenes [23]. This reaction is believed to pass through the formation of an intermediate glycol (1,2-diol) is oxidized further by breaking carbon-carbon bonds [24].
Synthesis of analogues curcumin product is a condensation reaction between two different carbonyl compounds known to the cross aldol condensation. This reactions involving aromatic aldehyde compounds and compounds alkyl or aryl ketone as a reactant known as reaction Claisen-Schmdt. Stages of aldol condensation reaction is divided into two phases: phase addition and dehydration [7]. Piperonal is an aromatic aldehyde compounds that can be reacted with carbonyl compounds other so as to produce curcumin analogues. Synthesis of analogues curcumin through condensation reaction between aromatic aldehydes with carboxylic acids to produce symmetrical [29, 33] and the process can be accelerated by using a microwave $[5,9]$. In microwave heating, solvent and solvent particles are heated causing uneven heating [26]. The mechanism of microwave heating is dipolar polarization, interfacial polarization, and conduction mechanism [15].

\section{Material and Methods}

\subsection{Material}

Kulit lawang oils from Maluku-Indonesia, $\mathrm{NaOH}, \mathrm{KOH}$, $\mathrm{KMnO}_{4}, \quad \mathrm{CH}_{3} \mathrm{COOH}, \quad \mathrm{Na}_{2} \mathrm{SO}_{4}, \quad \mathrm{H}_{2} \mathrm{SO}_{4}$, Diethyl ether, petroleum ether, Dichloromethane, Methanol, Tween 80 (Brataco), acetone, and all other chemicals were purchased from Sigma Chemical Co. (USA).

\subsection{Isolation Safrole}

$137.42 \mathrm{~g}$ kulit lawang oil was added $40 \mathrm{~g}$ of $\mathrm{NaOH}$ in 300 $\mathrm{mL}$ of aquades. The mixture was stirred to form two layers, and then the upper layer was separated. The bottom layer was extracted twice with $100 \mathrm{~mL}$ of petroleum ether and added to the top layer, then washed with distilled water until neutral and dried with $\mathrm{Na}_{2} \mathrm{SO}_{4}$ anhydrous. Petroleum ether was separated using evaporator and conducted distillation at reduced pressure. Product tested by gas chromatography, ${ }^{1} \mathrm{H}$ NMR and IR.

\subsection{Isomerization of Safrole}

Into a three-neck flask $500 \mathrm{~mL}$ size that has been equipped with a magnetic stirrer, thermometer, cooling tube, blue silica gel and then added $71.56 \mathrm{~g}(0.44 \mathrm{~mol})$ safrole and $50 \mathrm{~g}(0.89$ mol) $\mathrm{KOH}$. The mixture was refluxed at a temperature of 120 ${ }^{\circ}$ for 6 hours, and cooled then added $250 \mathrm{~mL}$ of aquades and then extracted with diethyl ether. Results dried with $\mathrm{Na}_{2} \mathrm{SO}_{4}$ and diethyl ether separated using evaporator. Purification was performed using distilled under reduced pressure and purity was tested by GC, the structure was determined by FTIR and ${ }^{1} \mathrm{H}-\mathrm{NMR}$.

\subsection{Synthesis of Piperonal}

Into a $250 \mathrm{~mL}$ three-neck flask included $2,97 \mathrm{~g}(0.02 \mathrm{~mol})$ isosafrol, $100 \mathrm{~mL}$ aquades, $2 \mathrm{ml} \mathrm{CH} \mathrm{CHOH}_{3} \mathrm{CO} \mathrm{ml} \mathrm{H}_{2} \mathrm{SO}_{4}$ $50 \%, 100 \mathrm{mg}$ twin 80 and $100 \mathrm{~mL}$ dichloromethane. Further $9.79 \mathrm{~g}$ (0.062 mol) $\mathrm{KMnO}_{4}$ was added about $500 \mathrm{mg}$ every 
minute, the temperature is $<30{ }^{\circ} \mathrm{C}$ by placing in an ice bath. After $\mathrm{KMnO}_{4}$ added, the flask is heated slowly at $40{ }^{\circ} \mathrm{C}$ until the purple color disappeared (15 minutes). The solution is cooled for a few minutes and precipitate $\mathrm{MnO}_{2}$ filtered using silica gel. Separation of the resulting solution is then poured into a separating funnel and the layers separated. Water layer (upper layer) was extracted with dichloromethane $(2 \times 30$ $\mathrm{mL})$. All organic layers are combined, and then washed with $2 \times 30 \mathrm{~mL}$ aquades. The organic layer was dried with $\mathrm{Na}_{2} \mathrm{SO}_{4}$, filtered and evaporated at the evaporator. The residue was added $20 \% \mathrm{NaOH}$ solution and the mixture was stirred for 30 minutes. Furthermore, the mixture was extracted with dichloromethane, washed with aquades, dried with $\mathrm{Na}_{2} \mathrm{SO}_{4}$ anhydrous and evaporated back. Recrystallization performed using methanol, the results obtained were analyzed by GC, FTIR, and ${ }^{1} \mathrm{H}-\mathrm{NMR}$.

\subsection{Synthesis of Analogues Curcumin by Microwaves Methods}

$15 \mathrm{~g}(0.1 \mathrm{~mol})$ piperonal, $2.9 \mathrm{~g}(0.05 \mathrm{~mol})$ acetone and 10 $\mathrm{mL}$ methanol included in Erlenmeyer. The mixture was stirred and included $5 \mathrm{~mL}$ of $10 \% \mathrm{NaOH}$. The mixture was stirred and put in the microwave at power 140 watts for 2 minutes. The residue was washed with methanol, filtered, and the results were analyzed.

\subsection{Synthesis of Analogues Curcumin by Conventional Methods}

$15 \mathrm{~g}(0.1 \mathrm{~mol})$ piperonal, $2.9 \mathrm{~g}(0.05 \mathrm{~mol})$ acetone and 10 $\mathrm{mL}$ methanol included in beaker. The mixture was stirred and included $5 \mathrm{~mL}$ of $10 \% \mathrm{NaOH}$. The mixture was stirred for 3 hours at a temperature of $25{ }^{\circ} \mathrm{C}$, the residue was washed with methanol, filtered, and the results were analyzed.

\section{Results and Discussion}

\subsection{Isolation Safrole}

Safrole can be separated from kulit lawang oils by using $\mathrm{NaOH}$. Eugenol and other phenolic components will react with $\mathrm{NaOH}$ to form water-soluble salts and formed two layers that can be separated, safrole layer which is not soluble in water are at the top of the mixture. Safrole was then purified using fractionation distills at pressure reduction. In Fraction 2 at temperatures $90-123^{\circ} \mathrm{C} / 1 \mathrm{mmHg}$ obtained safrole with yield $19.30 \%$. The properties of the resulting safrole is a clear liquid form, fragrant, insoluble in water but soluble in ethanol, chloroform and ether. Safrole analysis using gas chromatography obtained with a purity of $89.186 \%$ safrole. Infrared spectrum of safrole shows absorption bands in the region $3000-2800 \mathrm{~cm}^{-1}$ which is the absorption $\mathrm{C}_{\mathrm{sp} 3}-\mathrm{H}$, this was confirmed by the appearance of absorption at 1442.7 $\mathrm{cm}^{-1}$ for $-\mathrm{CH}_{2}$ - (methylene). Uptake range of $\mathrm{C}=\mathrm{C}$ aromatic absorptions appeared at $1608.5 \mathrm{~cm}^{-1}$ and is supported by absorption at $3150-3000 \mathrm{~cm}^{-1}$ which is the absorption band for $=\mathrm{C}_{\mathrm{sp} 2}-\mathrm{H}$ (aromatic). Absorption band at $1247.9 \mathrm{~cm}^{-1}$ region and $1041.5 \mathrm{~cm}^{-1}$ shows the range of $\mathrm{C}-\mathrm{O}-\mathrm{C}$ (ether) supported by each tape $916.1 \mathrm{~cm}^{-1}$ and $808,1 \mathrm{~cm}^{-1}$. Analysis and interpretation safrole ${ }^{1} \mathrm{H}-\mathrm{NMR}$ spectrum of $60 \mathrm{MHz}(\delta$ : $\mathrm{ppm})$ are as follows; $\delta=3.2 \mathrm{ppm}\left(\mathrm{d},-\mathrm{CH}_{2^{-}}\right), \delta=5.0 \mathrm{ppm}(\mathrm{d}$ $\left.=\mathrm{CH}_{2}\right), \delta=5.5$ to $6.2 \mathrm{ppm}(\mathrm{m},=\mathrm{CH}-), \delta=5.9 \mathrm{ppm}(\mathrm{s},-\mathrm{O}-$ $\left.\mathrm{CH}_{2}-\mathrm{O}-\right), \delta=6.8 \mathrm{ppm}(\mathrm{m}, 3 \mathrm{H}$ Ar). Safrole analysis using mass spectrum gives the following description, $(\mathrm{m} / \mathrm{z}): 39$, 51, 63, 77, 91, 104, 119, 131, and $162\left[\mathrm{C}_{10} \mathrm{H}_{10} \mathrm{O}_{2}\right]^{+}$(base peak).

\subsection{Isomerization of Safrole}

Safrole isomerization into isosafrol can be carried on without solvent system using $\mathrm{KOH}$ at $120{ }^{\circ} \mathrm{C}$ for 8 hours and obtained yield $77.56 \%$. The properties of the resulting isosafrole is light yellow viscous liquid and fragrant. Analysis using gas chromatography obtained cis-isosafrol the 3 rd peak with a retention time of 3.375 minutes $(15.40 \%)$ and trans-isosafrole the peak-to-5 with a retention time of 3.700 minutes $(69.34 \%)$.

Infrared spectrum of isosafrole showed absorption at area $3000-2800 \mathrm{~cm}^{-1}$ which is $\mathrm{C}_{\mathrm{sp} 3}-\mathrm{H}$ absorption. Absorption range of $\mathrm{C}=\mathrm{C}$ aromatic appeared at $1608.5 \mathrm{~cm}^{-1}$. Absorption band $\mathrm{C}_{\mathrm{sp} 2}-\mathrm{H}$ (aromatic) appears in the area $3150-3000 \mathrm{~cm}^{-1}$, this conclusion is supported by the presence of sharp band with moderate strength at $1490.9 \mathrm{~cm}^{-1}$. Absorption at 1247.9 to $1091.6 \mathrm{~cm}^{-1}$ shows the range of the C-O-C. Analysis by ${ }^{1} \mathrm{H}-$ NMR-60 MHz $(\delta: \mathrm{ppm})$ are as follows; $\delta=1.8 \mathrm{ppm}(\mathrm{d}$, $\left.\mathrm{CH}_{2}\right), \delta=5.9 \mathrm{ppm}\left(\mathrm{s},-\mathrm{O}-\mathrm{CH}_{2}-\mathrm{O}-\right), \delta=6.3 \mathrm{ppm}(\mathrm{d},-\mathrm{CH}=), \delta$ $=6.7-6.9 \mathrm{ppm}(\mathrm{d}, \mathrm{H} \mathrm{Ar})$.

\subsection{Synthesis of Piperonal}

Piperonal properties produced in the form of white crystals and fragrant, insoluble in water but soluble in methanol (mp $=56-57^{\circ} \mathrm{C}$ ). The results obtained by recrystallization using methanol piperonal to yield $65.63 \%$. Infrared spectrum of piperonal obtained their range $\mathrm{C}=\mathrm{C}$ aromatic appearing on uptake $1604.7 \mathrm{~cm}^{-1}$ is supported by absorption above 3000 $\mathrm{cm}^{-1}$ as absorption $\mathrm{C}_{\mathrm{sp} 2}-\mathrm{H}$ (aromatic). Absorption area between $3000-2800 \mathrm{~cm}^{-1}$ which indicates the absorption $\mathrm{C}_{\mathrm{sp} 3}$ $\mathrm{H}$ are reinforced by the presence of absorption $1448.9 \mathrm{~cm}^{-1}$ and $1357.8 \mathrm{~cm}^{-1}$ for methylene group $\left(-\mathrm{CH}_{2}-\right)$. Aldehyde group is shown by the presence of a weak absorption in the area twins $2711.7 \mathrm{~cm}^{-1}$ and $2781.2 \mathrm{~cm}^{-1}$ which is very typical for aldehyde compound. This was confirmed by uptake $1689.5 \mathrm{~cm}^{-1}$ which shows the carbonyl group. Absorption band $1249.8 \mathrm{~cm}^{-1}, 1099.3 \mathrm{~cm}^{-1}$ and $1037.6 \mathrm{~cm}^{-1}$ shows the compound ether (C-O-C). The loss of a double bond isosafrole characterized by loss of absorption areas at 962.4 $\mathrm{cm}-1$.

Analysis by ${ }^{1} \mathrm{H}-\mathrm{NMR}$ piperonal yield spectrum with the following peaks $\left(\delta\right.$ : ppm); $\delta=5.9 \mathrm{ppm}\left(\mathrm{d},-\mathrm{O}-\mathrm{CH}_{2}-\mathrm{O}-\right), \delta=$ $6.9 \mathrm{ppm}(\mathrm{d}, 1 \mathrm{H} \mathrm{Ar}), \delta=7.2 \mathrm{ppm}(\mathrm{d}, 2 \mathrm{H} \mathrm{Ar}), \delta=9.9 \mathrm{ppm}(\mathrm{d}$, $\mathrm{CH}=\mathrm{O}$ ). Hints of the data $1 \mathrm{H}-\mathrm{NMR}$ is a powerful clue oxidation of the double bond isosafrole is $\delta=9.9$ ppm peak which is the aldehyde proton unprotected because the induction effect of the carbonyl oxygen atom which is electronegative. 


\subsection{Synthesis of Analogues Curcumin (1,5-Bis- benzo[1,3/dioxol-5-yl-penta-1,4-dien-3-one)}

Product condensation piperonal with acetone obtained yellow crystals for both methods, but the product by conventional methods have greater yield when compared with microwave method is $78.43 \%\left(\mathrm{mp}=191{ }^{\circ} \mathrm{C}\right)$ and $53.3 \%\left(\mathrm{mp}=180{ }^{\circ} \mathrm{C}\right)$. Condensation reaction using conventional methods to produce analog of curcumin better. In terms of reaction time, the microwave method is better but has a weakness for volatile solvents, in this case methanol. Heating by using microwaves can increase the reaction rate of 10 to 1000 times if compared to conventional heating [27]. On heating by microwaves, the solvent will reach a boiling point very quickly and superheating events, namely the achievement of a higher boiling point rather than the actual boiling point when compared to conventional heating.
Therefore, the time required for the reaction becomes shorter, because the solvent molecules are located between reactant molecules experience a temperature increase dramatically and will create a much faster reaction.

The synthesis of analogues of curcumin used basic catalysts is $\mathrm{NaOH}$, because under alkaline conditions will form the enolate anion is more reactive than the enol form produced by the acid catalyst. Analogues curcumin 1,5-Bisbenzo [1,3] dioxol-5-yl-penta-1,4-dien-3-one can be obtained by condensation of acetone with two equivalent piperonal. The reaction begins with hydroxide ions in $\mathrm{NaOH}$ removes a proton from the carbon $\alpha$ the acetone molecules to form an enolate ion. Enolate ions will act as the nucleophilic in addition reaction with piperonal molecules produce an alkoxide ion. Alkoxide ion will accept a proton from water to form aldol [24]. The mechanism of the reaction between piperonal, acetone, and $\mathrm{NaOH}$ is estimated as follows:<smiles>C=C([O-])CCCCCCCCC(C)=O</smiles><smiles>CC(=O)CC(O)c1ccc2c(c1)OC[C@H]2O[Na]</smiles><smiles>CC(=O)/C=C/c1ccc2c(c1)OCO2</smiles><smiles>C=C([O-])/C=C/c1ccc2c(c1)OCO2</smiles><smiles>CCCCC(=O)Nc1ccc2c(c1)OC(CC)O2</smiles><smiles>CC1Oc2ccc(/C=C/C(=O)/C=C/c3ccc4c(c3)OC(C(O)C(=O)/C=C/c3ccc5c(c3)OCO5)O4)cc2O1</smiles>

Figure 1. Mechanism Reaction Synthesis of analogues curcumin (1,5-Bis-benzo[1,3]dioxol-5-yl-penta-1,4-dien-3-one).

The results of identification using LC-ESI MS to conventional methods obtained product at a retention time 3:38 minutes (Figure 2) and to methods of microwave $\mathrm{tR}=$ $2.98 \mathrm{~min}$ (Figure 3 ). The value of $\mathrm{m} / \mathrm{z}$ molecular ion and ion fragments of curcumin analogues with conventional methods were detected for the $[\mathrm{M}]^{+}=323 ;[\mathrm{M}+\mathrm{Na}]=345 ;[2 \mathrm{M}+\mathrm{Na}]=$
667; $[3 \mathrm{M}+\mathrm{Na}]=990$ (Figure 4). The value of $\mathrm{m} / \mathrm{z}$ molecular ion and ion fragments of curcumin analogues with micro wave method were detected for the $[\mathrm{M}]^{+}=323$; $[\mathrm{M}+\mathrm{Na}]=$ $345 ;[2 \mathrm{M}+\mathrm{Na}]=667 ;[3 \mathrm{M}+\mathrm{Na}]^{+}=991$ (Figure 5). From these data it can be concluded that the obtained target compound with a molecular weight of $322 \mathrm{~g} / \mathrm{mol}$. 


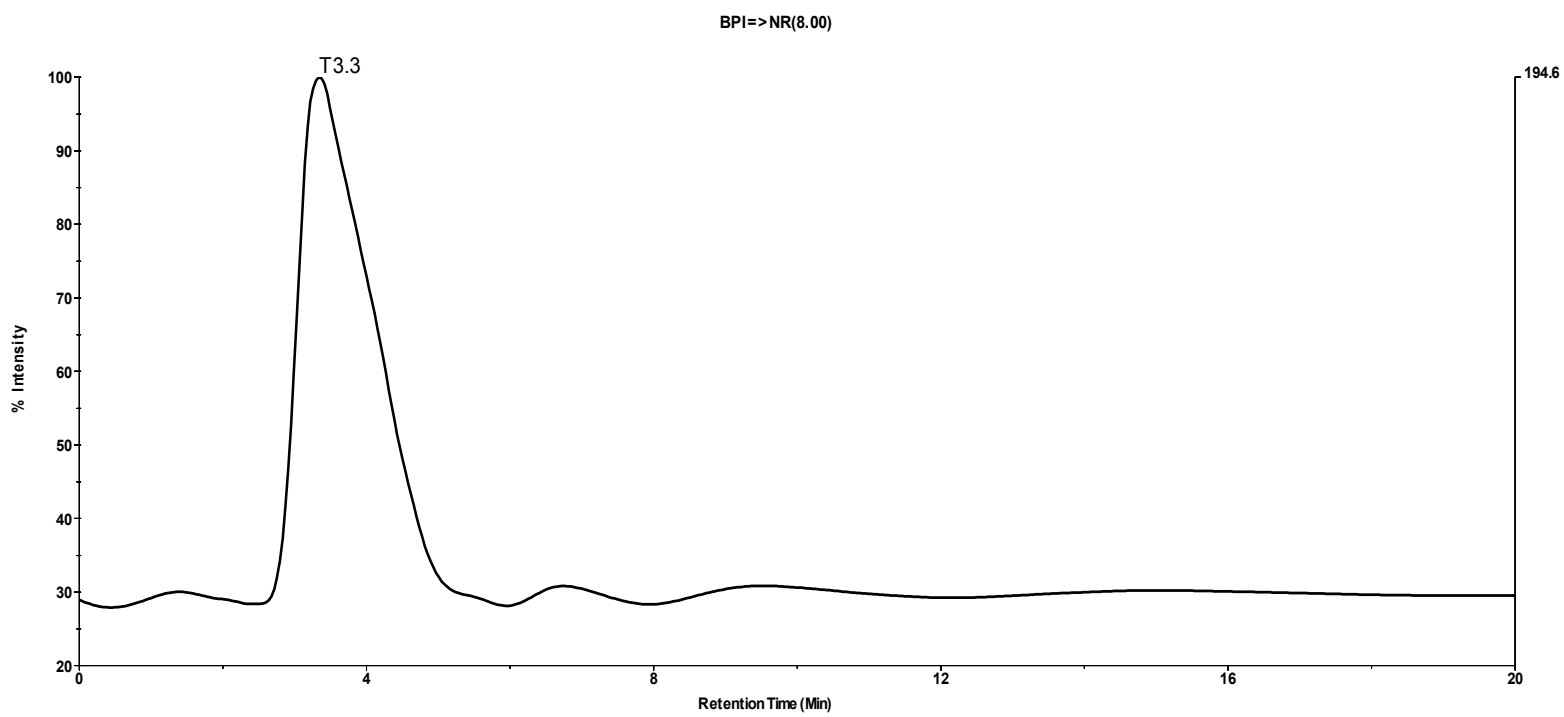

Figure 2. Retention time conventional methods.

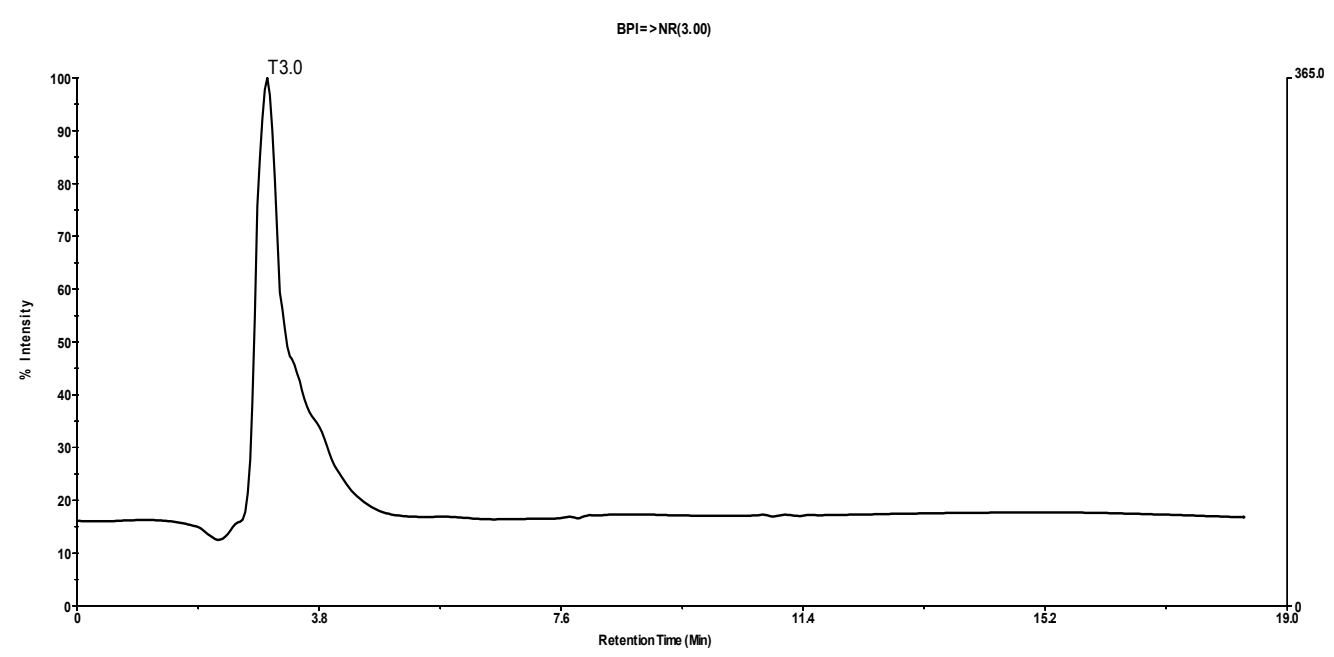

Figure 3. Retention time microwaves methods.

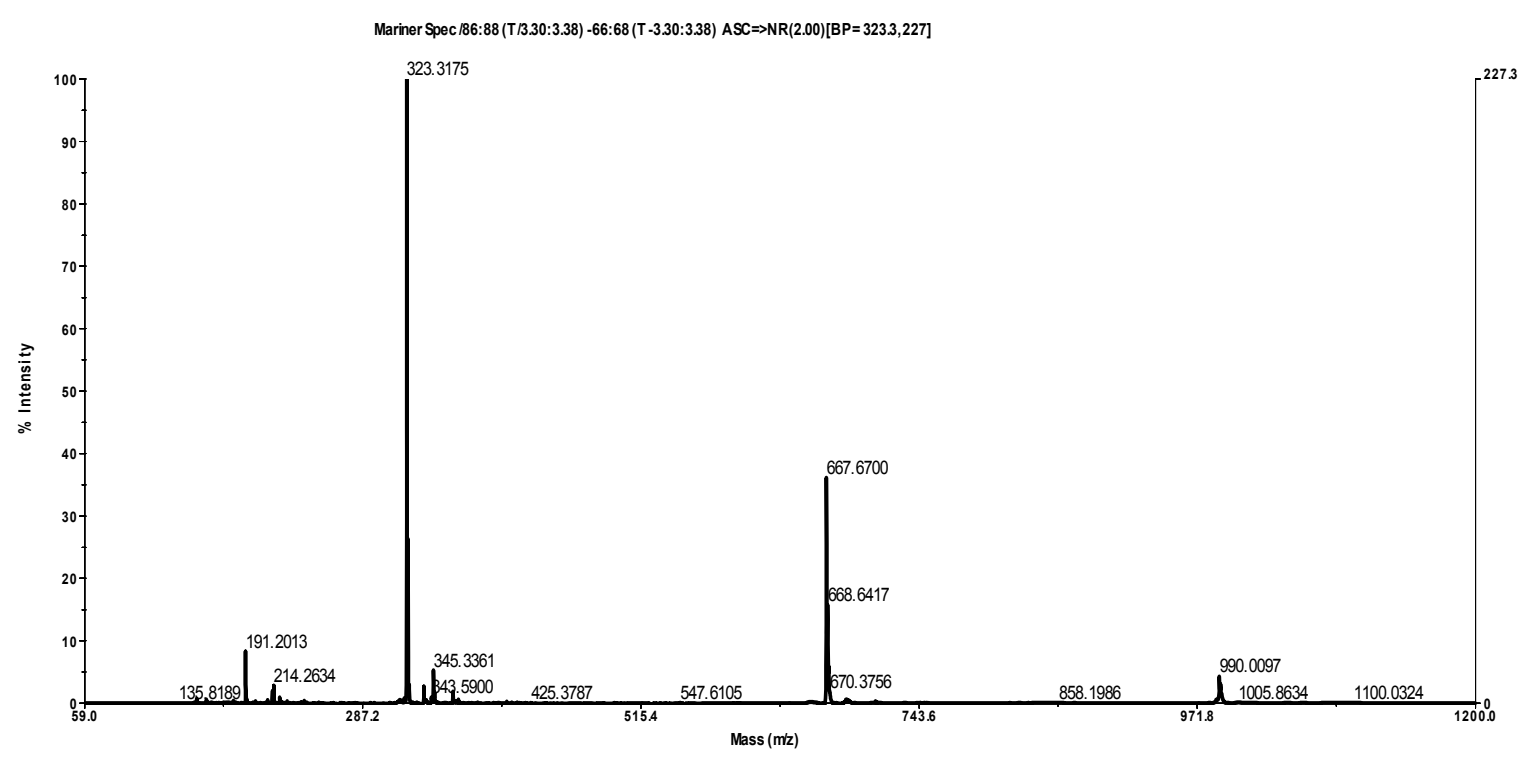

Figure 4. Spectrum MS conventional methods. 


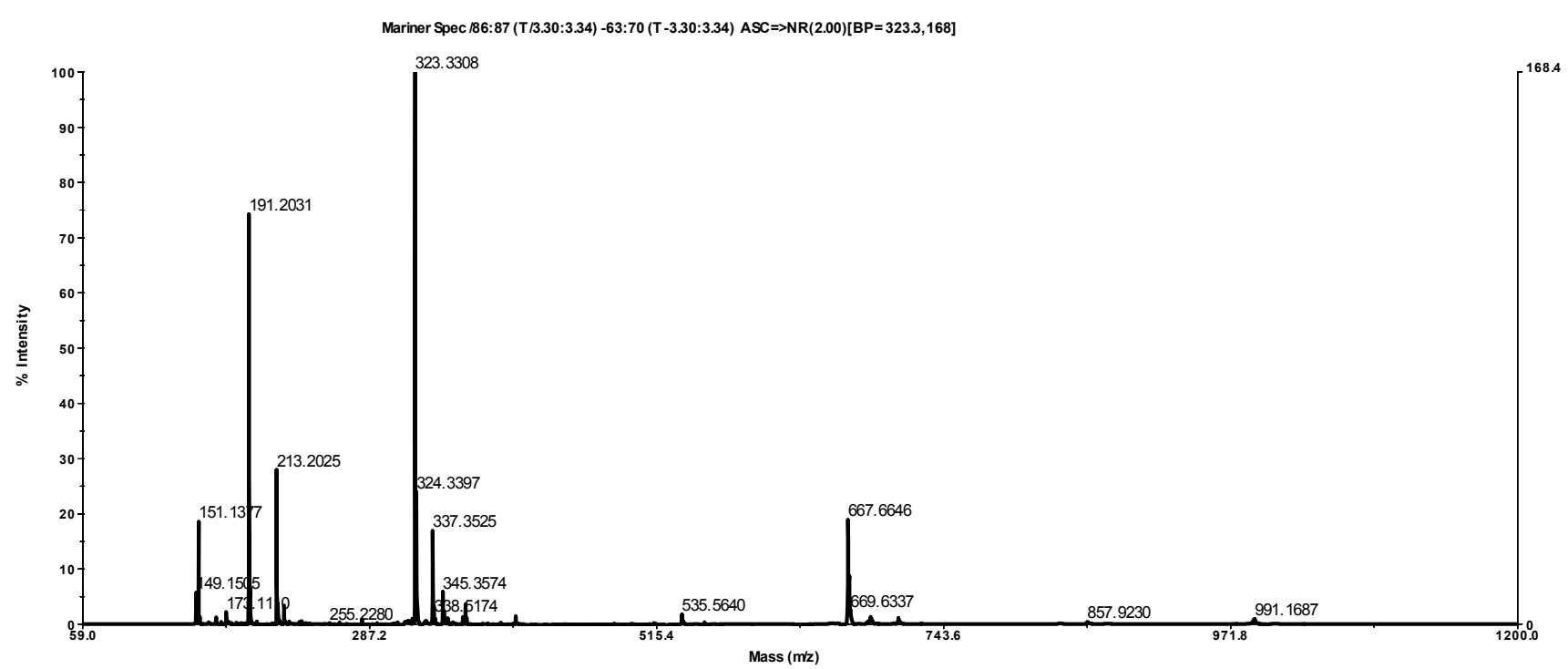

Figure 5. Spectrum MS microwaves methods.

\section{Conclusions}

Curcumin analogues (1,5-Bis-benzo [1,3] dioxol-5-ylpenta-1,4-dien-3-one) can be synthesized using precursor piperonal and acetone under alkaline conditions using conventional method (78.43\%) and microwave (53.3\%). The solvent used in the condensation process greatly affect yield results. Precursor piperonal obtained from the oxidation reaction isosafrole using $\mathrm{KMnO}_{4}$ generate yield $65.63 \%$. Purification using silica gel and climate control in the oxidation process may increase yield results. Isosafrol results isomerization without using a solvent to produce yield of $77.56 \%$. Safrole isolated from kulit lawang oils using alkaline extraction method produce yield of $19.3 \%$. Percent alkaline were added for the extraction must be proportional to the eugenol percent contained in the oil.

\section{References}

[1] Anand P, Bokyung S, Kunnumakkara AB, Kallikat N, Rajasekharan, Aggarwal BB. 2011. Suppression of proinflammatory and proliferative pathways by diferuloylmethane (curcumin) and its analogues dibenzoylmethane, dibenzoylpropane, and dibenzylideneacetone: Role of Michael acceptors and Michael donors. Journal Biochemical Pharmacology. 82:1901-1909.

[2] Anand P, Chitra S, Sonia J, Kunnumakkara AB, Aggarwal BB. 2008. Curcumin and cancer: An "old-age" disease with an "age-old" solution. Cancer Letters. 267:133-164.

[3] Anand P, Thomas SG, Kunnumakkara AB, Sundaram C, Harikumar KB, Sung B, Tharakan ST, Misra K, Priyadarsini IK, Rajasekharan KN, Aggarwal BB. 2008. Biological activities of curcumin and its analogues (Congeners) made by man and Mother Nature. Journal Biochemical Pharmacology. 76:1590-1611.

[4] Allinger NL, Cava MP, De Jongh DC, Johnson CR, Leber A, Steven CL. 1976. Organic Chemistry. 2nd ed. New York:Worth Pulisher.
[5] Azarifar D, Ghasemnejad H. 2003. Microwave-assisted synthesis of some 3,5-arylated 2-pyrazolines. Molecules. 8:642-648.

[6] Bezerra1 BD, Castro FO, Alves APNN, Pessoa C, Moraes MO, Silveira ER, Lima MAS, Elmiro FJM, Costa-Lotufo LV. 2006. In vivo growth-inhibition of Sarcoma 180 by piplartine and piperine, two alkaloid amides from Piper. Brazilian journal of medical and biological research. 39:801-807.

[7] Carey FA, Sunberg RI. 1990. Advanced organic chemistry. Reaction and synthesis. Part b ed 3. New York: Plenum Press.

[8] Devasena T, Rajasekaran K N, Menon VP. 2002. Bis-1,7-(2hydroxyphenyl)-hepta-1,6-diene-3,5-dione (a curcumin analog) ameliorates dmh-induced hepatic oxidative stress during colon carcinogenesis. Pharmacological research. 46:1

[9] Elavarasan S, Bhakiaraj D, Elavarasan T, Gopalakrishnan M. 2013. An efficient green procedure for synthesis of some fluorinated curcumin analogues catalyzed by calcium oxide under microwave irradiation and its antibacterial evaluation. Journal of chemistry. ID 640936.

[10] Guenther E. 1990. Minyak Atsiri. Edisi 1. Penerjemah Ketaren S. UI Press Jakarta.

[11] Hahm ER, Gho YS, Park S, Park C, Kim KW, Yang CH. 2004. Synthetic curcumin analogs inhibit activator protein-1 transcription and tumor-induced angiogenesis. Biochemical and Biophysical Research Communications. 321:337-344.

[12] Jin X, Zhang ZH, Sun E, Tan XB, Li SL, Cheng XD, You M, Jia XB. 2013. Enhanced oral absorption of 20(S)protopanaxadiol by self-assembled liquid crystalline nanoparticles containing piperine: in vitro and in vivo studies. International Journal of Nanomedicine. 8:641-652.

[13] Kapelle IBD, Rosmawati. 2010. Sintesis khalkon 3-(3",4"metilendioksi)-2ehidroksifenil prop-2-enon dari minyak kulit lawang. Journal of Pharmaceutical Science "Media Farmasi”. Universitas Ahmad Dahlan-Yogyakarta. 9:57-67.

[14] Ketaren S. 1985. Pengantar teknologi minyak atsiri. Jakarta : Balai Pustaka. 
[15] Lam SS, Chase HA. 2012. A review on waste to energy processes using microwave pyrolysis. Energies. 5:4209-4232.

[16] Labbozzetta M, Baruchello R, Marchetti P, Gueli MC, Poma P, Notarbartolo M, Simoni D, D'Alessandroa N. 2009. Chemico-Biological Interactions. 181:29-36.

[17] Liang G, Shao L, Wang Y, Zhao C, Chu Y, Xiao J, Zhao Y, Li X, Yang S. 2009. Exploration and synthesis of curcumin analogues with improved structural stability both in vitro and in vivo as cytotoxic agents. Journal Bioorganic \& Medicinal Chemistry. 17:2623-2631.

[18] Mehta A, Kaur G, Chintamaneni M. 2012. Piperine and quercetin enhances antioxidant and hepatoprotective effect of curcumin in paracetamol induced oxidative stress. International Journal of pharmacology. 8(2):101-107.

[19] Moorthi C, Kathiresan K. 2013. Curcuminpiperine/curcumin-quercetin/ curcumin-silibinin dual drugloaded nanoparticulate combination therapy: a novel approach to target and treat multidrug-resistant cancers. Journal of Medical Hypotheses and Ideas. 7:15-20.

[20] Sastrohamidjojo H. 2004. Kimia Minyak Atsiri. Yogyakarta: UGM Press.

[21] Shabestary N, Khazaeli S, Hickman R. 1998. Phase-transfer catalytic reactions. Journal of chemical education. 75(11):1470-1472.

[22] Shang YJ, Jin XL, Shang XL, Tang JJ, Liu GY, Dai F, Qian YP, Fan GJ, Liu G, Zhou B. 2010. Antioxidant capacity of curcumin-directed analogues: Structure-activity relationship and influence of microenvironment. Journal Food Chemistry. 119:1435-1442.

[23] Smith MB. 1994. Organic Synthesis. USA: Mc.Graw hill.

[24] Solomons TWG. 1990. Fundamentals of Organik Chemistry. Third Edition. New York: John Wiley \& Sons.

[25] Soliman G. 2005. Effect of curcumin, mixture of curcumin and piperine and curcum (turmeric) on lipid profile of normal and hyperlipidemic rats. The Egyptian Journal of Hospital Medicine. 21: 145 - 161.

[26] Tellez HM, Alquisira JP, Alonso CR, Cortes JGL, Toledano CA. 2011. Comparative kinetic study and microwaves nonthermal effects on the formation of poly(amic acid) 4,4'(hexafluoroisopropylidene)diphthalic anhydride (6fda) and 4,4'-(hexafluoroisopropylidene)bis(-phenyleneoxy) dianiline (baphf). Reaction activated by microwave, ultrasound and conventional heating. Int. J. Mol. Sci. 12:6703-6721.

[27] Taylor, M. 2005. Development in Microwave Chemistry. Evalueserve. United Kingdom.

[28] Villegas AM, Catalan LE, Venegas IM, Garcia JV, Altamirano HC. 2011. New catechol derivatives of safrole and their antiproliferative activity towards breast cancer cells. Molecules. 16:4632-4641.

[29] Youssef D, Nichols DC, Cameron TS, Balzarini J, Clercq ED, Jha A. 2007. Design, synthesis, and cytostatic activity of novel cyclic curcumin analogues. Bioorganic \& Medicinal Chemistry Letters. 17:5624-5629.

[30] Xiang YM, Li Y, Yin H, Zhang J. 2012. Curcumin: updated molecular mechanisms and intervention targets in human lung cancer. International Journal of Molecular Sciences. 13:39593978.

[31] Zhang Q, Zhong Y, Yan LN, Sun X, Gong T, Zhang ZR. 2011. Synthesis and preliminary evaluation of curcumin analogues as cytotoxic agents. Journal Bioorganic \& Medicinal Chemistry Letters. 21:1010-1014.

[32] Zhang Q, Fu Y, Wang HW, Gong T, Qin Y, Zhang ZR. 2008. Synthesis and cytotoxic activity of novel curcumin analogues. Chinese Chemical Letters. 19:281-285.

[33] Zhao C, Yang J, Wang Y, Liang D, Yang X, Li X, Wu J, Wu X, Yang S, Li X, Liang G. 2010. Synthesis of mono-carbonyl analogues of curcumin and their effects on inhibition of cytokine release in LPS-stimulated RAW 264.7 macrophages. Journal Bioorganic \& Medicinal Chemistry. 18:2388-2393. 